DOI: 10.34015/2523-4552.2021.2.06

УдК 343.341

Герасименко М. М.,

аспірант Академії праці,

соціальних відносин і туризму

ORCID: 0000-0002-4236-1715

Ховпун О. C.,

доктор юридичних наук, доцент, завідувач кафедри кримінального права, процесу та криміналістики Академії праці, соціальних відносин і туризму

ORCID:0000-0002-5753-966X

\title{
КРИМІНАЛЬНО-ПРАВОВА ХАРАКТЕРИСТИКА ГЕНОЦИДУ: СВІТОВА ПРАКТИКА ВСТАНОВЛЕННЯ ЧИСЕЛЬНОСТІ ЖЕРТВ
}

Розкриваючи питання кримінально-правової характеристики злочину геноциду української нації у 1932-1933 рр., автор досліджує світову практику встановлення чисельності жертв особливо тяжкого злочину. Цінність даного наукового дослідження полягає в тому, що міжнародний досвід надає можливість криміналістам, слідчим, експертам, історикам та дослідникам використовувати методологію, методи та спеціальні методики у ході проведення судових експертиз, історико-правових досліджень та під час встановлення чисельності жертв від злочину геноциду, вчиненого комуністичним тоталітарним режимом.

Крім того, проаналізовано висновок судової науково-демографічної експертизи Інституту демографії та соціальних досліджень імені М. В. Птухи НАН України від 30 листопада 2009 р

Ключові слова: українці; геноцид; злочин; світовий досвід; етнічна група, комуністичний тоталітарний режим; криміналістика; трибунал.

Раскрывая вопрос уголовно-правовой характеристики преступления геноцида украинской нации в 1932-1933 гг., автор исследует мировую практику установления численности жертв особо тяжкого преступления. Ценность данного научного исследования заключается в том, что международный опыт позволяет криминалистам, следователям, экспертам, историкам и исследователям использовать методологию, методы и специальные методики в ходе проведения судебных экспертиз, историко-правовых исследований и при установлении численности жертв преступления геноцида, совершенного коммунистическим тоталитарным режимом.

Кроме того, проанализировано заключение судебной научнодемографической экспертизы Института демографии и социальных исследований имени М. В. Птухи НАН Украины от 30 ноября 2009 г. 
Ключевые слова: украинцы; геноцид; жертвы; мировой опыт, этническая группа; коммунистический тоталитарный режим; криминалистика; трибунал.

Постановка проблеми. Геноцид - особливо тяжкий злочин, за вчинення якого передбачена кримінальна відповідальність за статтею 442 Кримінального кодексу України. Досудові розслідування злочину геноциду, встановлення чисельності жертв та осіб причетних до його вчинення потребує спеціальних знань та умінь. Слідчі, експерти та криміналісти повинні чітко розуміти природу та характер особливо тяжкого злочину геноциду, а також використовувати сучасні методи та методики для його розкриття.

Аналіз останніх досліджень та публікацій. Науковою основою для підготовки вказаної статті стали наукові праці відомих українських вчених, таких як В. Василенко, В. Шепітько, М. Антонович, В. Скавронік, В.Сергійчук, А. Козицький, американських вчених та дослідників геноциду українців Б. Футея, А. Лозинського, а також матеріали архівної кримінальної справи № 475.

Постановка завдання. Метою статті $\epsilon$ розкриття кримінальноправової характеристики злочину геноциду та дослідження світової практики встановлення жертв геноцидів світу.

Виклад основного матеріалу. Загальновизнано, що термін «геноцид» запровадив у науково-правовий обіг Рафаель Лемкін у листопаді 1943 р. (у друкованому виданні з'явився у 1944 р.). Термін походить 3 грецької үદ́vos (рід, сім'я, плем'я) та латинської caedere (вбивати).
Генеральна Асамблея Організації Об'єднаних Націй $(\mathrm{OOH})$ у резолюції 96 (I) від 11 грудня 1946 р. оголосила, що геноцид є злочином, який порушує норми міжнародного права, суперечить духу і цілям Організації Об'єднаних Націй; цивілізований світ засуджує його, визнаючи, що протягом всієї історії геноцид завдавав великих втрат людству.

Конвенція ООН про запобігання злочину геноциду і покарання за нього від 9 грудня 1948 р., набула чинності 12 січня 1951 р. відповідно до статті XIII (витяг):

Стаття I. Договірні сторони підтверджують, що геноцид незалежно від того відбувається він у мирний чи воєнний час, є злочином, що порушує норми міжнародного права і проти якого вони зобов'язуються вживати заходів попередження і карати за його здійснення.

У статті II Конвенції під геноцидом розуміються такі дії, вчинені 3 наміром знищити, цілком чи частково, будь-яку національну, етнічну, расову чи релігійну групу як таку:

а) убивство членів такої групи; b) заподіяння серйозних тілесних ушкоджень чи розумового розладу членам такої групи; с) навмисне створення для будь-яку групи таких життєвих умов, що розраховані на повне чи часткове фізичне знищення іiі; d) заходи, спрямовані на запобігання дітонародження в середовищі такої групи; е) насильницька передача дітей з однієї людської групи в іншу.

У статті III визначено дії, що підлягають покаранню: а) геноцид; b) змова з метою вчинення геноциду; 
c) пряме і публічне підбурювання до вчинення геноциду; d) замах на вчинення геноциду; е) співучасть у геноциді.

Особи, що чинять геноцид чи будь-які з перерахованих у статті III дій, підлягають покаранню незалежно від того $\epsilon$ вони відповідальними по конституції правителями, посадовими чи приватними особами (стаття IV).

У статті V Конвенції передбачено проведення необхідних конституційних процедур з метою розробки ефективних заходів покарання осіб, винних у вчиненні геноциду чи інших згаданих у статті III злочинів (Українська РСР ратифікувала Конвенцію 15 листопада 1954 року).

Історичними прикладами реального притягнення до відповідальності осіб за геноцид $\epsilon$ рішення Нюрнберзького військового трибуналу щодо осіб, причетних до злочинів та масових вбивств під час Другої світової війни, Міжнародних трибуналів по Югославії й Руанді. Звинувачення у вчиненні злочину геноциду стало доволі поширеним у міжнародних та національних судових трибуналах впродовж останньої половини сторіччя. Судові інстанції встановлювали факти вчинення геноциду, винних осіб, обвинувачено та засуджено вчинення актів геноциду. Визнання на міжнародному рівні факту того, що Голодомор 1932-1933 років був геноцидом має позитивне значення як для України, так і для майбутнього розвитку міжнародного гуманітарного права [1, с. 58].

Необхідно також пам'ятати, що геноцид належить до низки злочинів, які підпадають під юрисдикцію Міжнародного кримінального суду. Стаття 25 Римського статуту
Міжнародного кримінального суду встановлює, що особа за причетність до злочину геноциду, пряме i публічне підбурювання інших до вчинення злочину геноциду буде нести індивідуальну кримінальну відповідальність. Юрисдикція Міжнародного кримінального суду вже частково визнана Україною.

Відповідно до Конвенції $\mathrm{OOH}$ «Про незастосування строку давності до воєнних злочинів і злочинів проти людства» від 26 листопада 1968 р., ратифікованою УСРР 25 березня 1969 р. (Ст. 1), строки давності не застосовуються щодо злочину геноциду [2].

Частиною п'ятою статті 49 Кримінального кодексу України давність як підстава для звільнення від кримінальної відповідальності не застосовується у разі вчинення злочинів проти основ національної безпеки України, передбачених у статтях 109-114, проти миру та безпеки людства, передбачених у статтях 437-439 i частині першій статті 442 Кримінального кодексу України.

На виконання Конвенції $\mathrm{OOH}$ про запобігання злочину геноциду і покарання за нього від 9 грудня 1948 р., Верховною Радою України встановлено кримінальну відповідальність за злочин геноцид, передбачений статтею 442 КК України [3, c. 131].

Вказана Конвенція ООН імплементована в диспозицію статті 442 КК України та $є$ вирішальним критерієм для юридичної оцінки злочину геноциду.

Геноцид українців 19321933 pр., вчинений комуністичним тоталітарним режимом, досі чекає свого визнання. Лише 1 кримінальна справа та 1 кримінальне проваджен- 
ня за 30 років незалежності України та неспроможність української влади відповісти на такі питання: який механізм задіяв тоталітарний режим для масових вбивств; яку чисельність українців було знищено; а також встановити обставин та наслідки особливо тяжкого злочину проти української нації. Міжнародна спільнота та українська громада не почула відповіді на вказані питання.

Саме тому під час досудових розслідувань злочину геноциду необхідно використовувати міждисциплінарний підхід та загальнонаукові i спеціальні методи криміналістики - науки про закономірності злочинної діяльності та їі відображення в джерелах інформації, які слугують основою для розроблення засобів, прийомів i методів збирання, дослідження, оцінки й використання доказів 3 метою встановлення осіб, причетних до вчинення протиправних дій, притягнення їх до кримінальної відповідальності, встановлення обставин та наслідків, а також розробки механізмів запобігання злочинам.

Кримінально-правова характеристика злочину геноциду будується на підставі системи обставин, які входять до предмета доказування, а саме:

Об'єктом злочину геноциду 1932-1933 рр. є безпека існування етнічних, національних, расових та релігійних груп.

Потерпілою стороною від даного злочину $\epsilon$ українська нація спільнота людей, об'єднана назвою, символами, географічним, етнокультурним та етносоціальним походженням, історичною пам'яттю, духовно-культурними і політичними цінностями.
Об'єктивна сторона злочину геноциду 1932-1933 рр. - характеризується суспільно-небезпечними діями комуністичного тоталітарного режиму, спрямованими на знищення української нації як такої, створюючи для українців життєві умови, розраховані на повне або часткове їх фізичне знищення, позбавлення реальної можливості забезпечувати себе достатнім харчуванням, заподіяння їм тяжких тілесних ушкоджень, масових вбивств, депортації та насильницьку передачу дітей з однієї групи в іншу.

Місце вчинення злочину - це територія УСРР, українські історичні етнічні землі та місця компактного проживання українців в РСФРР, де відбувалися суспільно небезпечні діяння - геноцид української нації.

Час вчинення злочину - це певний відрізок (проміжок) часу, протягом якого відбуваються суспільно небезпечні діяння і настають суспільно небезпечні наслідки. В цьому випадку злочин геноцид вчинений комуністичним тоталітарним режимом у 1932-1933 pp.

Обставини вчинення протиправних дій - злочин геноцид проти української нації вчинено за обтяжуючих обставин.

Суб'єктивна сторона злочину геноциду 1932-1933 рр. характеризується прямим умислом, спрямованим на знищення комуністичним тоталітарним режимом української нації як такої.

Наприклад, у травні 1933 р. в аналітичному звіті «Голод і українське питання» К. консул Королівства Італії в Харкові С. Граденіго писав, що політика московського уряду «...має на меті за кілька місяців ліквідувати 
українську проблему, пожертвувавши 10 чи 15 мільйонами душ... не доведеться більше говорити ні про Україну, ні про український народ, а, отже, не буде й української проблеми, оскільки Україна фактично стане частиною Росії...» [4, с. 159].

Спеціальна мета злочину знищення національно-визвольного руху та недопущення відновлення незалежної Української держави.

Суб'єкт злочину геноциду (загальний) - це фізична осудна особа, яка досягла 16-річного віку.

Спеціальний суб'єкт злочину геноциду - керівництво комуністичного тоталітарного режиму СРСР, керівники Комуністичної партї̈ (більшовиків) України та каральних органів, які є організаторами та виконавцями злочину геноциду.

Світова практика встановлення чисельності жертв геноцидів

За результатами проведених досліджень, автором проаналізовано світову практику встановлення чисельності жертв геноцидів вірмен, євреїв, казахів, ромів та тутсі.

Так, під час вчинення злочину геноциду вірмен у 1915-1916 рр. на території Османської імперії за різними джерелами знищено від 300 тис. до 1,2 млн вірмен із 1,5 млн, що проживали на території Османської імперії. Турецька влада визнала, що в 1915-1916 рр. загинуло 300 тис. вірмен (вбиті, загинули від голоду i хвороб). Згідно з даними Міжнародної асоціації дослідників геноциду (IAGS), загиблих було понад 1 млн. Вірменія заявила, що загинуло 1,5 млн осіб. Сполучені Штати Америки визнали геноцид вірмен в Османській імперії та верхню межу жертв геноциду - 1,5 млн осіб [5].
У часи Другої світової війни (1939-1945 рр.), за різними джерелами, було знищено, зникли безвісти та зазнали переслідувань до 6 млн євреїв, $з$ них 1,5 млн дітей та 1,5 млн євреїв, котрі були виселені у 19411945 рр. углиб території СРСР. У даному випадку за основу також взята верхня межа, яка становить 6 млн осіб [6, с. 50-67].

Комуністичний тоталітарний режим у 1932-1933 роках вчинив злочин геноцид проти казахів. Казахські дослідники у 1989 році визначила втрати у 1 млн 750 тис. казахів. Офіційна комісія парламенту Казахстану в грудні 1992 року зробила висновок про те, що від колективізації та голоду загинуло 2 млн 200 тис. казахів.

Проте, остаточну чисельність жертв геноциду в Казахстані ще не визначено. Казахи продовжують розсекречувати архіви, проводять історико-правові дослідження та здійснюють пошук документів, з метою встановлення історичної правди. Сучасні дослідження казахських вчених свідчать, що під час геноциду Казахстан втратив понад 4 млн казахів [7, с. 10].

За різними дослідженнями у 1939-1945 рр. нацистами було знищено від 200 до 500 тис. ромів. Під час визначення остаточної чисельності жертв геноциду ромів взята верхня межа - 500 тис. осіб. Постановою Верховної Ради України «Про відзначення Міжнародного дня голокосту ромів» від 8.10.2004 p. № 2085-IV жертвами геноциду визнано 500 тис. ромів [8].

Геноцид тутсі у Руанді розпочався 7 квітня 1994 р. В цей день урядові війська, поліція та воєнізовані підрозділи етнічної більшості 
країни - гуту, розпочали знищення етнічної меншості - тутсі. Масові вбивства тривали 100 днів.

Міжнародна правозахисна організація «Human Rights Watch» дійшла висновку, що під час геноциду було знищено 507 тис. тутсі Експерти ООН визначили загальні втрати у 800 тис. осіб, тобто верхню межу досліджень.

Міжнародний кримінальний трибунал щодо Руанди (МКТР) виніс обвинувальні вироки проти 93 обвинувачених. Станом на жовтень 2017 р. 62 особи було засуджено, 14 виправдано, 10 справ з 93 було передано Трибуналом із обвинувальними висновками до національних юрисдикцій для судового розгляду. Троє обвинувачених залишаються на свободі, двоє померли до судового розгляду, у двох випадках провадження було припинене до судового розгляду. Десять країн світу, заарештували та передали підозрюваних у вчиненні злочину геноциду тутсі до МКТР [9, c. 133].

Чотирьох організаторів засудив суд Бельгії до довічного ув'язнення. Бельгійські суди активно використовують міжнародне законодавство. Спеціальні слідчі підрозділи мають право розслідувати військові злочини, злочини проти безпеки людства та геноциди, вчинені за межами країни. Це позитивний світовий приклад притягнення до кримінальної відповідальності організаторів та виконавців злочину геноциду. В судах Руанди розглянуто понад 1 млн справ.

Аналіз архівних кримінальних справ, що стосуються злочинів нацистського режиму, також свідчить про те, що слідчі, прокурори, криміналісти та експерти при встановленні обставин та наслідків злочинів використовували спеціальні криміналістичні методи і брали за основу верхню межу жертв.

На підставі викладеного, автор дійшов до висновку, що під час проведення історико-правових досліджень чи судових експертиз для встановлення чисельності жертв геноциду українців у 1932-1933 рр., слідчим, прокурорам, криміналістам, експертам, історикам та дослідникам за основу потрібно брати (враховувати) верхню межу жертв. Це світова практика. Крім того, слід зазначити, що жодна із країн світу до цього часу не змогла встановити індивідуально кожну жертву злочину геноциду, незважаючи на скрупульозні дослідження чи кримінальні розслідування.

Важливо також звернути увагу на те, що злочини геноциду здійснювалися під час воєн та збройних конфліктів. В Україні злочин геноциду був вчинений під час боротьби українців за відновлення Української держави.

У ході проведення дослідження автор проаналізував судову науководемографічну експертизу Інституту демографії та соціальних досліджень імені М. В. Птухи НАН України від 30 листопада 2009 р. та дійшов висновку, що дані викладені в експертизі не відповідають реальній чисельності знищених українців комуністичним тоталітарним режимом у 19321933 рр. За результатами експертизи прямі втрати населення УСРР внаслідок злочину геноциду становили 3 млн 941 тис. (через надсмертність), непрямі - 1 млн 122 тис. (дефіцит народжень), сукупні демографічні 5 млн 63 тис., а 3 урахуванням куму- 
лятивних втрат - 10 млн 63 тис. осіб [10].

Дослідження демографів та статистиків у 1930-х роках, а саме: М. Птухи, О. Асаткіна, А. Хоменка, які, використовуючи статистичні дані, визначили втрати української нації відповідно - 6 млн 700 тис., 7 млн 100 тис., 7 млн 700 тис. (без врахування 1 млн необлікованих смертей зафіксованих відділом населення ЦУНГО) та М. Курмана - 8 млн українців. Офіційні документи іноземних дипломатів вказують про знищення 9-16 млн українців.

Таким чином, невідповідність даних експертизи, проведеної Інститутом демографії та соціальних досліджень імені М. В. Птухи НАН України (3 млн 941 тис.) відносно першоджерел $є$ очевидною та свідчить про недостовірність висновку.

Співробітники СБ України, які приймали участь у розслідуванні кримінальної справи, неодноразово заявляли, що вказана експертиза не відображає повну картину сукупних та кумулятивних демографічних втрат, дослідження щодо встановлення чисельності жертв необхідно продовжувати [11, с. 361].

Під час розслідування кримінальної справи № 475 слідчий зробив помилку, доручивши проведення експертизи щодо встановлення чисельності жертв геноциду Iнституту демографії та соціальних досліджень імені М.В.Птухи Національної академії наук України, тобто установі, яка взагалі не займається питаннями історико-правових досліджень. Демографічні методи та методики, не стосуються питань розкриття злочинів, встановлення обставин та їх наслідків.
Генеральна прокуратура України ще у вересні 2009 р. звернула увагу слідчого на те, що призначена судова науково-демографічна експертиза не вирішує спектр питань для надання правової оцінки у кримінальній справі та надала вказівку залучити до їі проведення економістів, юристів, судових медиків, істориків та політологів [12, c. 28-29].

Крім того, про те, що «..дані про кількість "прямих втрат" українських селян від геноциду, що містяться в матеріалах кримінальної справи, в інших надійних, загальновизнаних, авторитетних джерелах, яких дотримується більшість зарубіжних та вітчизняних дослідників вказаного злочину тоталітарної сталінської системи, суттєво різняться...», зазначив у своїй статті В. Скавронік, заслужений юрист України, суддя у відставці, який розглядав кримінальну справу № 475 (Матеріали Міжнародної конференції «Штучні голоди в Україні ХХ століття» (Київ, 16 травня 2018 року). Київ-Дрогобич: Видавництво «Коло», 2018. С. 296).

Відповідно до вимог чинного законодавства України та міжнародного права, розслідування і розкриття злочинів, проведення судових експертиз, встановлення обставин та наслідків, а також притягнення винних до кримінальної відповідальності $\epsilon$ винятковою компетенцією слідчих, прокурорів, криміналістів та судових експертів, а не будь-яких інших фахівців. Демографічні методики, якими користується класична демографія, не застосовуються при підрахунку жертв злочину геноциду, воєн, епідемій, соціальних та природних катаклізмів. Демографічні 
розрахунки опираються виключно на сталі демографічні фактори, тобто коли сталими $\epsilon$ всі внутрішні демографічні процеси та кількісні показники відтворення населення (коефіцієнт народжуваності, смертності, зміни населення), також сталими залишаються закономірності їх зміни.

Використання під час проведення судової науково-демографічної експертизи для встановлення чисельності жертв геноциду демографічних розрахунків «надсмертності», «середньої смертності» тощо $\epsilon$ недопустимим. Термін «надсмертність», не відповідає вимогам кримінального та кримінального процесуального права. Він має медичне походження i застосовується для опису рівня та динаміки смертності із природних причин, серед осіб із вродженими патологіями, або набутими важкими захворюваннями (туберкульоз, малярія, рак, діабет та ін.), через шкідливий вплив зовнішніх обставин (хімічне або радіаційне забруднення навколишнього середовища, стрес тощо), ускладнення при пологах.

У медичному значенні термін «надсмертність» вживає у своїй документації Всесвітня організація охорони здоров'я [13]. Саме у такому значенні термін вживається Організацією Об'єднаних Націй, наприклад, в останньому звіті «Зміна рівнів та тенденцій смертності: роль патернів смерті за причинами», який присвячено аналізу тенденцій природної смертності у світі у період 2008-2010 pp. [14, с. 61]. Українська медична термінологія також містить це визначення у медичному значенні, не пов'язаному із зумисною політикою масового винищення [15, c. 142-148].
Будь-який термін, що претендує на об'єктивність, має бути універсально придатним для всіх аналогічних ситуацій, у цьому конкретному випадку - всіх прикладів масового винищення людей тоталітарними режимами або всіх випадків геноциду. Отже, спроба експерта застосувати до встановлення чисельності знищених українців під час геноциду 19321933 рр. термін «надсмертність» не відповідає стандартам наукової номенклатури та не може бути використаний для надання кримінальноправової оцінки злочину.

Медичний термін «надсмертність» категорично не вживається щодо геноцидів вірмен, євреїв, ромів, казахів, тутсі, як в науковому середовищі жодної країни, а також серед політиків, правників, істориків, публіцистів, громадських діячів. У даному випадку мова йде про масове винищення національних, етнічних груп, тому вживаються правові терміни й визначення, а не медичні чи будь які інші.

Чому не можна використовувати демографічні закони для встановлення наслідків злочинів та гіпотетично вираховувати чисельність жертв, пояснив судово-медичний експерт вищої кваліфікаційної категорії за спеціальністю «судовомедична експертиза», кандидат медичних наук А. В. Кісь: «Не можна огульно виокремити серед тих померлих, хто складав би так званий “середній річний показник смертності"... хоча б тому, що аж ніяк неможливо прийняти те, що стара або хвора людина, яка можливо, ще й дожила б до листопада 1933 р., помирає у травні з голоду, а ми за "правилами демографії та статистики” 
викреслюємо їі зі списку загиблих Звучання мотиву “все одно помер (-ла, -ли) би того ж року" як пояснення демографічних законів має дуже поганий присмак» [16, с. 149].

Під час проведення судової науково-демографічної експертизи при розрахунку втрат за основу взято чисельність населення УСРР 31 млн 700 тис. осіб (станом на 01.01.1932 р.). Однак, згідно 3 «Довідником 3 основних статистичноекономічних показників господарства районів», чисельність населення України на початок 1932 р. фактично становила 32 млн 680 тис. 700 осіб., 3 них сільське населення 25 млн 553 тис. осіб (78,2\%), міське - 7 млн 127 тис. 700 осіб (21,8\%) [17].

Крім того, слід звернути увагу, що при проведенні демографічних розрахунків експерт взяв період 1932-1934 рр. Однак, слідчий поставив питання щодо встановлення жертв злочину геноциду у 19321933 рр. [18, с. $329-343]$.

Також необхідно врахувати, що за даними сільгоспподаткового обліку наркомату фінансів станом на червень 1934 р., сільське населення України становило 19 млн 374 тис 100 осіб. Отже, навіть за радянськими статистичними даними, лише сільське населення УСРР протягом січня 1932 р. - червня 1934 р. скоротилося на 6 млн 178 тис. 900 осіб. Крім того, до цієї цифри необхідно додати 1 млн випадків необлікованих зафіксованих смертей (за даними відділу населення ЦУНГО) [19, c. 42-43]. Отже, офіційна радянська статистика свідчить, що втрати української нації лише у сільській місцевості становлять 7 млн 178 тис. 900 осіб.
Комуністичний тоталітарний режим також знищував голодом, репресіями, депортаціями українців, які проживали в містах. Висновком судово-медичної експертизи від 30.10.2009 р. № 153-ДМ/09 встановлено, що у 1933 р. в м. Харків голодом було знищено 100 тис. українців. У висновку судово-медичної експертизи від 10.11.2009 р. № 16о-ДМ/09, проведеної Харківським бюро судово-медичних експертиз, також зазначено про знищення голодом 100 тис. українців в м. Харків лише в 1933 р. Сотні тисяч українців було знищено й в інших містах.

Представник Швеції в ПАРЄ Горан Ліндблед у своєму виступі (на основі якого прийнята Резолюція ПАРЄ 1096 (1996) зазначав (витяг): «... Приблизно 5 мільйонів людей в результаті конфіскацій померли голодною смертю в 1921-1923 рр., особливо в Україні. Голод використовувався, як політична зброя при деяких комуністичних режимах, не тільки в Радянському Союзі.

Винищування від 300000 до 500000 козаків між 1919 і 1920 pp. Десятки тисяч людей, загиблих в концентраційних таборах. Тут, також відсутність доступу до архівів, робить дослідження неможливим. 690000 людей, довільно засуджених на смерть і страчених в результаті так званих чищень в комуністичній партії в 1937-1938 рр. Тисячі інших були заслані або поміщені в концентраційні табори. Загалом, між 1 жовтня 1936 p. і 1 листопада 1938 p. приблизно 1565000 людей було арештовано i 668305 з них були страчені. Згідно багатьом розслідуванням, ці цифри зменшені, і повинні бути перевірені, коли всі архіви стануть доступними. Масове знищення 
приблизно 30000 кулаків під час насильницької колективізації 19291933 pp. I подальша депортація 2 мільйонів в 1930-1932 pp. 6 мільйонів українців загинуло з голоду в ході добре продуманої державної політики в 19321933 роках...».

Таким чином, слід зробити наступний висновок: під час досудових розслідувань та історикоправових досліджень необхідно також враховувати депортацію українців за межі УСРР, що дасть можливість встановити чисельність жертв злочину геноциду 1932$1933 \mathrm{pp}$.

Під час дослідження кримінально-правової характеристики геноциду слід встановити елементи складу цього злочину. Об'єктом є безпека існування етнічних, національних, расових та релігійних груп.
Потерпілою стороною від злочину виступає вся українська нація.

Об'єктивна сторона злочину геноциду 1932-1933 рр. - характеризується суспільно-небезпечними діями комуністичного тоталітарного режиму, спрямованими на знищення української нації як такої, створюючи для українців життєві умови, розраховані на повне або часткове їх фізичне знищення, позбавлення реальної можливості забезпечувати себе достатнім харчуванням, заподіяння їм тяжких тілесних ушкоджень, масових вбивств, депортації та насильницьку передачу дітей з однієї групи в іншу. Суб'єктивна сторона злочину геноциду 1932-1933 рр. характеризується прямим умислом, спрямованим на знищення комуністичним тоталітарним режимом української нації як такої.

\section{Список використаних джерел}

1. Футей Б. Відповідальність за геноцид. Сучасність. 2008. № 11. С.58.

2. Конвенція про незастосування строку давності до воєнних злочинів і злочинів проти людства (995_168) від 26 листопада 1968 p. URL: https://zakon.rada.gov.ua/laws/show/995_168\#Text

3. Кримінальний кодекс України. Відомості Верховної Ради України (ВВР). 2001. № 25-26. С. 131.

4. Листи з Харкова. Голод в Україні та на Північному Кавказі в повідомленнях італійських дипломатів 1932-1933 роки / Італійський інститут культури в Україні. Харків: Фоліо, 2007. С. 159.

5. Григор Атанесян. США визнали геноцид вірмен 1915 року. Чому зараз? ВВС News Україна. 30. 10. 2019. URL: https://www.bbc.com/ukrainian/features-50232044 ; Джордан Карни. Сенат принял резолюцию о геноциде армян The Hill 12.12.19. URL: https://thehill.com/homenews/senate/474306-senate-passes-armenian-genocideresolution

6. Козицький А. Демографічні втрати українців від Голодомору 1932-1933 років у контексті підрахунку геноцидних жертв XX ст. Матеріали Міжнародної науковопрактичної конференції «Голодомор 1932-1933 років: втрати української нації» (Київ, 4 жовтня 2016 року). Київ, 2017. С. 50-67.

7. Казахстан. Коммерсантъ Власть. №16. 25.04.2016. С. 10.

8. Постанова ВРУ Про відзначення Міжнародного дня голокосту ромів. Відомості Верховної Ради Украӥни. 2005. № 2. Ст. 65. 
9. Вибір заради справедливості. Т. ІІ. Посібник зі створення механізмів притягнення до відповідальності за найтяжчі злочини. 2018. С. 133.

10. Вісник Служби Безпеки України. Спеціальний випуск. За матеріалами кримінальної справи про Голодомор-геноцид 1932-1933 років в Україні. Київ, 2010. Ч. 57.

11. Геноцид в Україні 1932-1933 рр. За матеріалами кримінальної справи № 475. Київ, 2014. С. 8; Голодомор 1932-1933 років в Україні як злочин геноциду згідно з міжнародним правом: Монографія / За наук. ред. В. Василенка, М. Антонови ч. Вид. 4-те, допов. Київ : Видавничий дім «Києво-Могилянська академія», 2016. С. 361.

12. Архівна кримінальна справа № 475. 2010. Т. 3. С. 28-29.

13. Excess mortality in persons with severe mental disorder. Geneva : World Health Organization, 2016. $81 \mathrm{p}$.

14. Changing Levels and Trends in Mortality: the role of patterns of death by cause. New York: United Nation, 2012. XVIII. 61 p.

15. Рингач Н. Надсмертність чоловіків: нагальна проблема українського соціуму. Журнал української лікарської еліти. 2009. № 1 (7). С. 75-78; Рингач Н. Проблема надсмертності чоловіків в Україні: ґендерний аналіз у державному управлінні охороною громадського здоров'я. Стратегічні пріоритети. 2008. № 3 (8). С. 142-148.

16. Кісь А. Судово-медична експертиза Голодомору 1932-1933 в Україні Матеріали Міжнародної конференції «Штучні голоди в Україні XX століття» (Київ, 16 травня 2018 року). Київ-Дрогобич : Видавництво «Коло», 2018. С.149.

17. Територія та населення станом на 1 січня 1932 р. Довідник основних статистично-економічних показників господарств районів Харківської області. Харків, $1933 \mathrm{p}$.

18. Геноцид в Україні 1932-1933 рр. За матеріалами кримінальної справи № 475. Упор. М. Герасименко. Київ, 2014. С. 329-343.

19. Численность населения: прогнозы и действительность. Жиромская В. Б., Киселев И.Н., Поляков Ю.А. Полвека под грифом «секретно»: Всесоюзная перепись населения 1937 года. Москва : Наука, 1996. С. 42-43.

\section{References}

Futej, B. (2008). Vidpovidal'nist' za henotsyd. Suchasnist', 11, 58.

Kozyts'kyj, A. (2017). Demohrafichni vtraty ukraintsiv vid Holodomoru 1932-1933 rokiv u konteksti pidrakhunku henotsydnykh zhertv KhKh st. Materialy Mizhnarodnoi naukovo-praktychnoi konferentsii «Holodomor 1932-1933 rokiv: vtraty ukrains'koi natsii» (Kyiv, 4 zhovtnia 2016 roku), 50-67.

Rynhach, N. (2009). Nadsmertnist' cholovikiv: nahal'na problema ukrains'koho sotsiumu. Zhurnal ukrains'koi likars'koi elity, 1 (7), 75-78.

Rynhach, N. (2008). Problema nadsmertnosti cholovikiv v Ukraini: gendernyj analiz u derzhavnomu upravlinni okhoronoiu hromads'koho zdorov'ia. Stratehichni priorytety, 3 (8), 142-148.

Kis, A. (2018). Sudovo-medychna ekspertyza Holodomoru 1932-1933 v Ukraini. Materialy Mizhnarodnoi konferentsii «Shtuchni holody v Ukraini KhKh stolittia» (Kyiv, 16 travnia 2018 roku). Kyiv-Drohobych: Vydavnytstvo «Kolo». 
M. Herasymenko, Postgraduate student of the Academy of Labor, social relations and tourism

ORCID: 0000-0002-4236-1715

A. Khovpun, Doctor of Law, Associate Professor, Head of the Department of Criminal Law, process and criminology Academy of Labor, Social Relations and Tourism ORCID:0000-0002-5753-966X

\section{Criminal-legal characteristics of genocide: the world practice of determining the number of victims}

The article is devoted to the examination of such a crime as genocide. The purpose of the article is to reveal the criminal-legal characteristics of genocide and to study the world practice of identifying victims of genocides.

Particular attention is paid to the criminal-legal characteristics of genocide in accordance with national and international legislation: the Criminal Code of Ukraine, the UN Convention on the Prevention and Punishment of the Crime of Genocide, the Rome Statute of the International Criminal Court, the UN Convention on the Non-Applicability of Statutory Limitations to War Crimes and Crimes Against Humanity.

The author analyzes the world practice of establishing the number of victims of the genocides of Armenians, Jews, Kazakhs, Roma and Tutsis. The conclusion of the forensic scientific and demographic examination of the Ptoukha Institute for Demography and Social Studies of the National Academy of Sciences of Ukraine dated November 30, 2009 is also being considered.

Keywords: Ukrainians; genocide; crime; international experience, ethnic group; interdisciplinary approach; communist totalitarian regime; criminalistics; tribunal. 